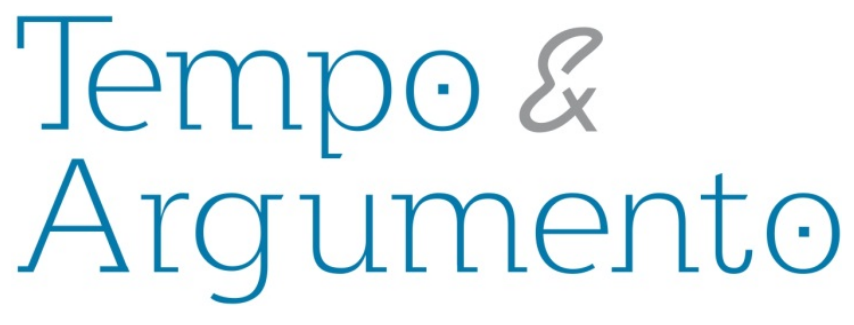

\title{
Humor e política na desconstrução dos super-heróis na América Latina durante a Guerra Fria: o olhar dos quadrinhos
}

\begin{abstract}
Resumo
Mídia associada ao cotidiano e entretenimento juvenil, as histórias em quadrinhos (HQs) alcançaram plena consolidação na América Latina durante os anos após a $2^{\mathrm{a}}$ Guerra Mundial. Quando da Guerra Fria e da forte penetração cultural dos Estados Unidos (EUA) na região, as HQs já se encontravam presentes em jornais, nos quais, por vezes, eram publicadas em suplementos específicos, além de serem editadas no formato revista por editoras especializadas. Em meio aos debates sobre as vantagens e desvantagens das HQs para a vida que já mobilizavam aqueles envolvidos no mundo das HQs, a questão do imperialismo cultural também motivou críticos e a produção local a buscar redefinir os sentidos desta mídia na América Latina. Uma das etapas passou pela efetiva defesa de uma "substituição de importações" da produção estrangeira, focando na criação local de quadrinhos que representassem a realidade nacional. Para tanto, era necessário desconstruir algumas das referências dos comics, de forma a colocá-los em xeque perante sua comunidade de leitores. $O$ presente artigo analisa tal processo a partir de dois estudos de caso: a cooperativa brasileira CETPA (Cooperativa Editora de Trabalhos de Porto Alegre) e a editora chilena Quimantú. Em ambas, o foco recaiu principalmente sobre os super-heróis, mesclando paródia e crítica política ao problematizar a atuação do superherói na América Latina. A partir das situações em análise, o artigo procura destacar tal etapa para o estabelecimento dos quadrinhos enquanto prática cultural na região.
\end{abstract}

Palavras-chave: História em Quadrinhos; Super-heróis; América Latina - História.

\section{Para citar este artigo:}

GOMES, Ivan Lima. Humor e política na desconstrução dos super-heróis na América Latina durante a Guerra Fria: o olhar dos quadrinhos. Revista Tempo e Argumento, Florianópolis, v. 8, n. 18, p. 40 - 67. maio/ago. 2016.

DOI: $10.5965 / 2175180308182016040$

http://dx.doi.org/10.5965/2175180308182016040 


\title{
Humor and politics to deconstruct superheroes in Latin America in Cold War years: the comics gaze
}

\begin{abstract}
Commonly associated with everyday life and juvenile entertainment, comics, reached a solid status in Latin America during post-Second World War years. During first Cold War years and the massive U.S. cultural penetration in the region that followed, comics were published in newspapers sometimes with exclusive supplements for them - and edited as comic books by specialized publishing houses. Adding a new aspect to the debate about possible advantages or disadvantages of comics for life that took part of the comics world during the 1950's, the cultural imperialism as an issue helped to reshape how the senses of comics in Latin America. An important step here was an effective defense of the "import substitution" of the foreign production, with a focus on a local creation of comics that represented national reality. For doing so, it was important to deconstruct several of the international comics references, to put them in doubt over the reader community of comics. This process will be discussed here through two case studies: the Brazilian comics cooperative CETPA (1961-1964) and major Chilean publishing house Quimantú (1971-1973). In both situations, the focus is centered here on superheroes, mixing parody and political critics when superhero actions in Latin America are problematized. The paper reaches to emphasize the relevance of such discussion to establish comics as a cultural practice in the region.
\end{abstract}

Keywords: Comics; Superheroes; Latin America - History.

\section{Introdução - Quadrinhos na História: super-heróis submetidos à análise}

Os personagens de histórias em quadrinhos (HQs) são capazes de realizar proezas das mais inacreditáveis. Alguns são representados como personagens dotados de superpoderes que lhes permitem não apenas voar e derrotar as forças do mal por meio da força física, mas também constituir todo um novo gênero narrativo (HATFIELD, HEER, WORCESTER, 2013); alguns solucionam mistérios lançando mão de recursos mágicos ou sobrenaturais; e há aqueles que simplesmente levam com bom humor os acontecimentos do dia a dia - o que talvez seja a maior de todas as façanhas possíveis. 
Tudo isso reservou aos personagens de HQs uma dimensão de inocência e pureza, historicamente ratificada pelas condições editoriais e visuais sob as quais foram forjadas: lançadas em jornais dominicais e, em seguida, na imprensa diária, serviam de alívio cômico às notícias de verdade do mundo adulto. De cores berrantes e traços por vezes caricaturais, em muitos casos, aos quadrinhos restou apenas a condescendência dos olhares tolerantes que viam neles nada mais do que uma diversão para jovens (GABILLIET, 2005, p. 1-8). Quando alcançaram autonomia editorial através das revistas, o caráter improvisado do formato gerou reações que oscilaram entre a indiferença e a desconfiança sobre esse produto voltado para crianças e jovens (GABILLIET, 2010; WRIGHT, 2001).

Ao olhar a história das HQs, tudo isso pode ser considerado em boa parte como verdadeiro, ao ponto dos quadrinhos não serem poupados nem mesmo no interior do próprio formato, como a produção expressiva de paródias de personagens e séries ao longo do tempo permite constatar (GROESTEEN, 2010; PEREIRA, 2011). Ao caráter trivial das HQs, deve ser acrescida outra história, que dê conta da participação dessa linguagem em questões de ordem social e política, historicamente localizadas em cada quadro e página.

A América Latina fornece campo fértil para discutir as relações entre HQs e política a partir do humor. Em contraste, chama atenção a relativa carência de estudos centrados na realidade latino-americana no atual campo denominado de comics studies (HEER, WORCESTER, 2009). À profusão de estudos centrados no recorte nacional, poucos trabalhos incorporam as recentes discussões em torno de abordagens atentas à circulação transnacional dos impressos para compreendê-los historicamente (PRADO, 2005, p. 11-33). Produção cultural associada às inovações técnicas ocorridas desde o século XIX (SMOLDEREN, 2009), os quadrinhos circulam entre países e se transformam a cada território que atravessam, num cruzamento que favorece a escrita de uma história dos cruzamentos e das circulações e produções de sentidos sobre eles. Afinal de contas, se os comics norte-americanos são historicamente construídos, eles podem ter o mesmo sentido em todo e qualquer contexto?

É possível afirmar que não, pelo menos no caso latino-americano. No período entre guerras, a lista de clientes da principal distribuidora de HQs norte-americana girava 
em torno de mil e duzentos veículos periódicos em todo o mundo, em 85 países e traduzidos para 27 línguas diferentes ${ }^{1}$. A partir das décadas de 1920 e 1930 é notória a presença expressiva de quadrinhos na região, introduzindo novas formas de contar histórias em imagens, mesclando-se a tradições gráficas e visuais locais, e proporcionando a criação de produtos híbridos. Longe de representarem modelos definitivos das maneiras como cada realidade nacional reagiu à presença dos comics em seus respectivos mercados editoriais, discutir contextos distintos pode contribuir para uma visão transnacional das circulações dos quadrinhos (STEIN, DENSON, MEYER, 2013).

Dois estudos de caso serão discutidos aqui. O recorte partiu da atuação editorial em contextos nos quais, de alguma forma, buscava-se discutir os sentidos dos quadrinhos numa dada realidade. No Brasil, a CETPA, uma pequena cooperativa lançada durante o governo estadual de Leonel Brizola, no Rio Grande do Sul, procurou operar uma efetiva "substituição de importações", lançando personagens de quadrinhos com temáticas nacionais e que questionavam a legitimidade estrangeira dos comics. No Chile, a grande editora Quimantú, alinhada com o projeto político da Unidad Popular de socialismo pela via democrática, buscou aplicar nas historietas parte das discussões críticas promovidas por intelectuais como Armand Mattelart, Ariel Dorfman e Manuel Jofré.

A partir das referências gerais da cultura nacional-popular (ARGUMEDO, 2009, p. 24-25), CETPA e Quimantú também trataram de enfrentar a questão dos quadrinhos como problema estético e político. Subjacente às fontes relacionadas a cada editora está presente a seguinte pergunta: o que significa publicar uma manifestação típica da sociedade capitalista como os quadrinhos em realidades historicamente “subdesenvolvidas" ou “terceiro-mundistas", para usar expressões típicas da época? Cada editora lidou com o problema com ênfases distintas, mas colocando em xeque uma figura comum: o super-herói.

O recurso visual predominante na problematização da figura do super-herói das HQs consistiu na ampla utilização de representações humorísticas. Ao longo de boa parte das tiras da brasileira Zé Candango predominou o uso do humor na desconstrução de

\footnotetext{
1 A bibliografia não é precisa. Moses Konigsberg (apud. GENÉ, 2012, p. 184), editor ligado a Hearst, estabelece o ano de 1919, ao passo que MacDougall (1942, p. 80) localiza seus dados "antes da [ $2^{\mathrm{a}}$ ] guerra".
} 
personagens das HQs; em Quimantú, tal abordagem foi precedida de um debate teórico sobre o super-herói, além de ter sido explicitada em HQ publicada na revista Cabrochico. A análise recai, portanto, no conjunto das tiras criadas por Canini e José Geraldo e numa HQ de Año 2.200 sustentada pelas discussões sobre os super-heróis travadas pelo chileno Manuel Jofré.

Devem ser destacadas novamente as diferenças entre cada experiência editorial. A tira Zé Candango durou nove meses na seção diária de quadrinhos veiculada na edição gaúcha de Última Hora, além de uma continuação ter saído entre 1963 e 1964 pelo Jornal do Brasil; o contraste com Año 2.000, cuja série não chegou a completar dez números em Cabrochico e não passou do ano de 1971, pode parecer um tanto desproporcional. Porém, o contraste entre formatos e durações distintos ressalta as nuances entre eles e as maneiras como cada contexto percebia os quadrinhos. Seguindo orientação comum aos teóricos da paródia, malgrado a sua intenção, ela exigiu o reconhecimento social de um cânone normalizador a ser mimetizado (JAMESON, 1985, p. 16-26; HUTCHEON, 1989, p. 118-119). Em outras palavras, a paródia implica em aceitar a existência de um modelo passível de ser apropriado e contestado. Afora a exceção de Año 2.200, em Quimantú optou-se por não representá-los visualmente, como se a editora não reconhecesse o cânone super-heróico no interior das HQs; em seu lugar, deveriam surgir outros heróis, baseado numa apropriação da realidade chilena pelos quadrinhos. Já a paródia em Zé Candango estabeleceu uma condição que não apenas assumiu e prestou tributo aos comics, como procurou ressaltar os limites que eles impunham ao mercado local de HQs.

\section{CETPA e a "substituição de importações" de quadrinhos}

A tira de José Geraldo e Renato Canini reunia personagens do gênero superheróico, como Superman, Batman e Capitão Marvel, aos quais foram adicionados outros heróis de aventura - Fantasma e Mandrake -, detetives - Dick Tracy e Agente X-9 -, personagens das selvas, humorísticos ou não - Brucutu e Jim das Selvas -, entre outros. A profusão de nomes e séries levou o "Capitão Maravilha Jr." - uma versão do Capitão Marvel - a declarar que "na minha terra existe atualmente uma verdadeira inflação de 
super-homens", tornando o trabalho "escasso"”. A partir da metáfora da inflação, tão cara ao contexto político e econômico vivido pelo país em 1962, explicava-se a presença de tantos heróis estrangeiros no Brasil de Zé Candango.

Havia, porém, um preço simbólico a ser pago para escapar da "inflação de superhomens" que afligia os "Estates". A visualização de diversos personagens dos comics ocorreu a partir da apropriação visual e temática das principais características de cada um, expondo-os ao crivo do leitor. Os personagens e toda a mitologia construída em torno deles ao longo dos anos pela comunidade de leitores de HQs foram desconstruídos a partir dos recursos da linguagem dos quadrinhos. Tudo começou com a convocação de Super-Super, escolhido por uma trupe de encapuzados para defender o Brasil. Arrogante e convencido, a alcunha de Super-Super reforçou o caráter arquetípico do personagem concebido por Siegel e Shuster. Ele chamou a atenção pelo seu corpo desproporcional e absurdo, assim como outros personagens que surgem em seguida, como Batman e Fantasma.

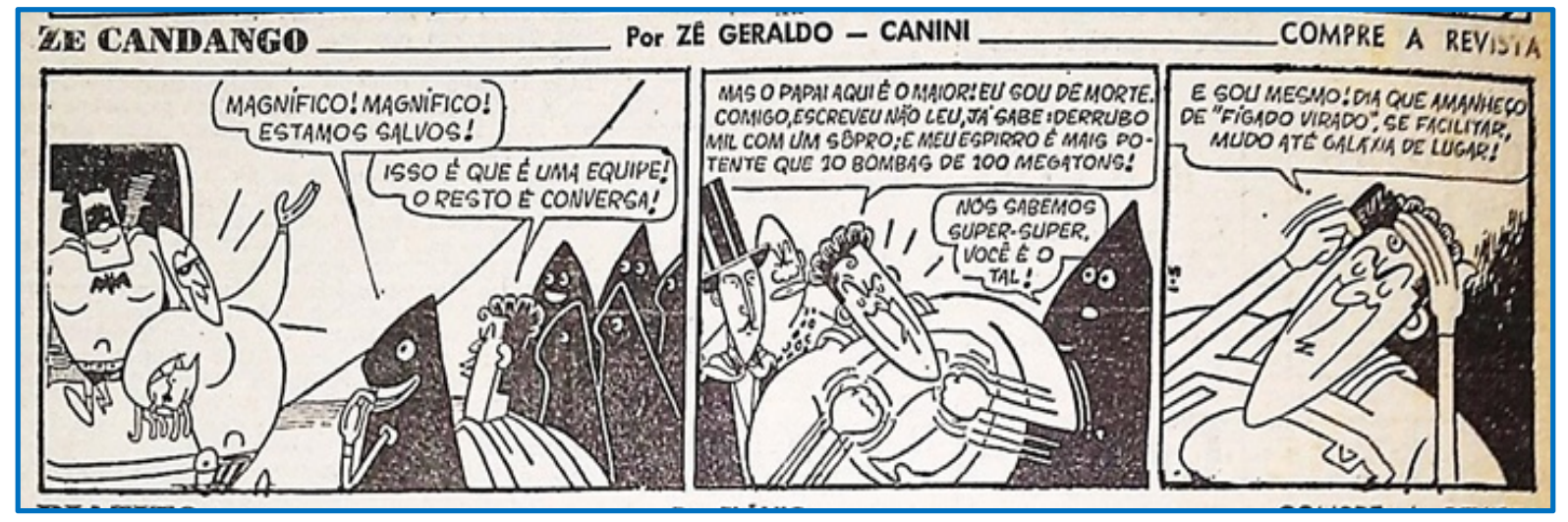

Figura 1 - Super-Super na Zé Candango.

Fonte: ZÉ CANDANGO. Última Hora, Porto Alegre, 20 out. 1962, p. 14

O quê, sob um primeiro olhar, eles apresentam em comum? Todos eles foram retratados como seres corpulentos e, pode-se deduzir, acima do peso. A força é um dos componentes definidores dos super-heróis: conforme constata Jennings a partir de Sturken e Cartwright, os super-heróis podem ser interpretados como representações do poder, reificados na dimensão física de seus corpos (JENNINGS, 2013, p. 59-63).

\footnotetext{
² ZÉ CANDANGO. Última Hora, Porto Alegre, 20 nov. 1962, p. 12.
} 
Outros personagens foram apresentados para compor uma equipe de superheróis, sob a liderança de "Super-Super". Seguindo o interesse que as revistas em quadrinhos manifestaram pela estética dos cowboys ao longo dos anos 1950, ícones do gênero lançados pelo cinema foram abordados na tira e inseridos junto aos cânones dos quadrinhos (SAVAGE JR., 1990, p. 66-67).

Logo de início se destacou a versão candanga de Roy Rogers, chamada "Roi Roi", que aparentava fragilidade; "lida com vacas mas [sic] está sempre cheiroso" e, diferente do personagem que lhe servira de inspiração, contemporâneo de nomes como Gene Autry, Tex Ritter e Dick Foran, que havia se tornado famoso pelas canções entoadas em muitos dos seus mais de 90 filmes, "Roi Roi” cantava uma “"besteira' qualquer” após matar “dez ou vinte”, para tristeza de seu cavalo (SLATTA, 1994, p. 129-130)․

Outro personagem que perdeu atributos fantásticos foi Mandrake. Até então considerado o maior mágico do mundo, desiludiu-se após uma visita à Comissão Federal de Abastecimento e Preços (COFAP) e constatou que os verdadeiros mágicos eram brasileiros. Curiosamente, quando da publicação dessa história, a COFAP já havia sido substituída por outro órgão federal, a Superintendência Nacional de Abastecimento (SUNAB), o que pode ser um indicativo de que a tira era produzida com alguma antecedência em relação à sua publicação. Além disso, o diálogo se passa no Rio de Janeiro e menciona São Paulo, o que parece reforçar a expectativa de que tiras como Zé Candango ultrapassassem os limites do regional.

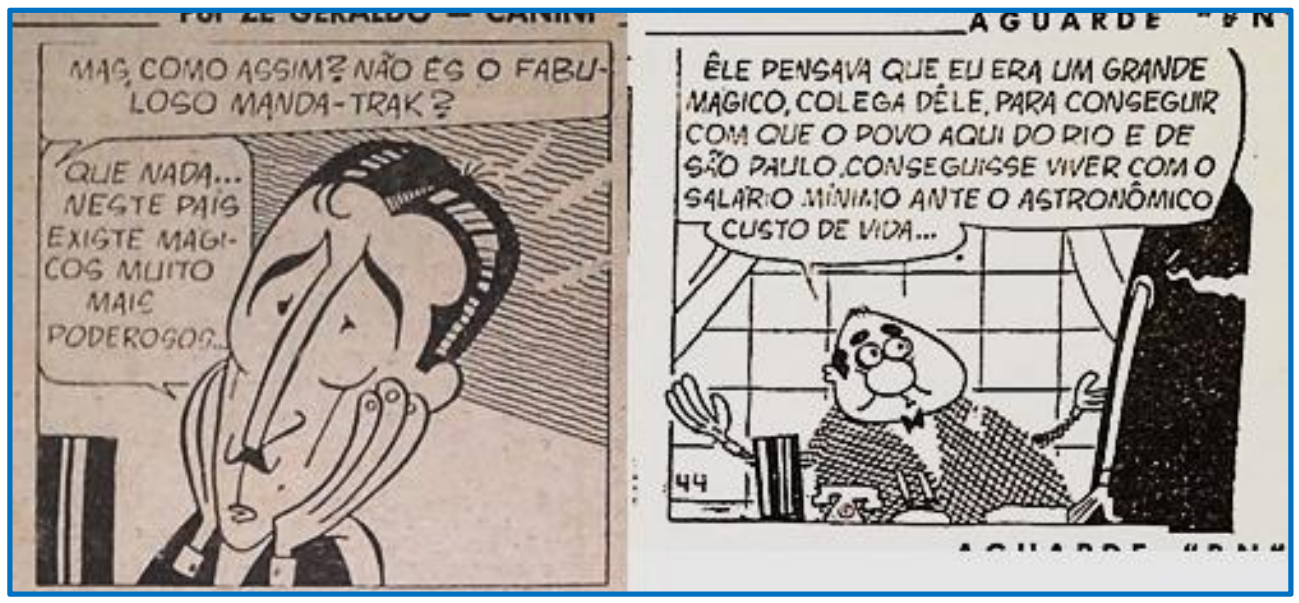

Figura 2 - Mandrake em Zé Candango (detalhes).

Fonte: ZÉ CANDANGO. Última Hora, Porto Alegre, 07 dez. 1962, p. 20. ZÉ CANDANGO. Última Hora, Porto Alegre, 08 dez. 1962, p. 16

${ }^{3}$ ZÉ CANDANGO. Última Hora, Porto Alegre, 22 out. 1962, p. 20. 
Brucutu, ser pré-histórico cujas aventuras em quadrinhos eram motivadas por viagens no tempo, chegou ao Brasil acompanhado do professor Papanatas com um objetivo: o de se "arrumar". Isso significava aproveitar as possibilidades econômicas que a inflação do país podia proporcionar a um viajante do tempo.

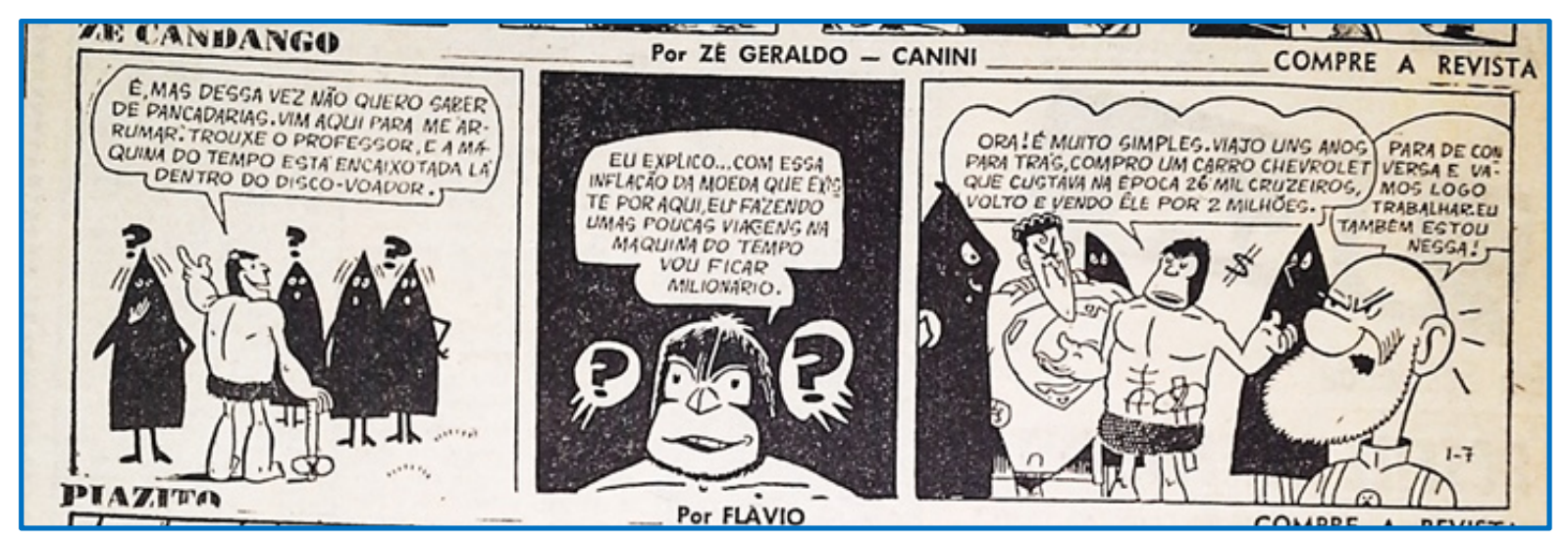

Figura 3 - Brucutu em Zé Candango.

Fonte: ZÉ CANDANGO. Última Hora, Porto Alegre, 23 out. 1962, p. 20.

A questão econômica, por outro lado, dificultou a manutenção de Popeye, ou "Papaye", como preferia a dupla de artistas da CETPA, na equipe de "supers". Se "na terra dele" quem pagava seu espinafre "são [eram] as firmas comerciais a título de anúncios", no Brasil tal iniciativa levaria a equipe à falência.

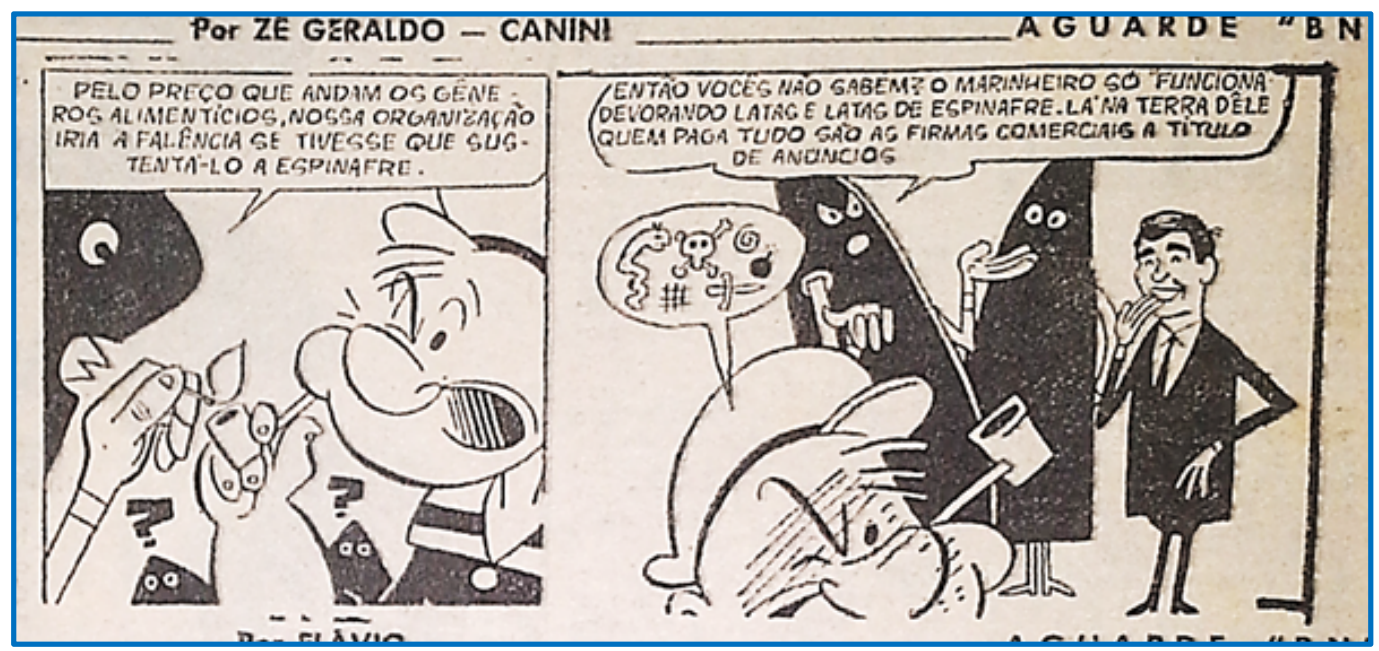

Figura 4 - Popeye em Zé Candango (detalhe).

Fonte: ZÉ CANDANGO. Última Hora, Porto Alegre, 29 nov. 1962, p. 16. 
Jim Gordo, um dos representantes das HQs de detetive, acreditava que havia sido convidado para o Brasil graças à sua capacidade de "descobrir espião" e pela sua experiência em "histórias em quadrinhos que se desenrolavam aqui na América do Sul”.

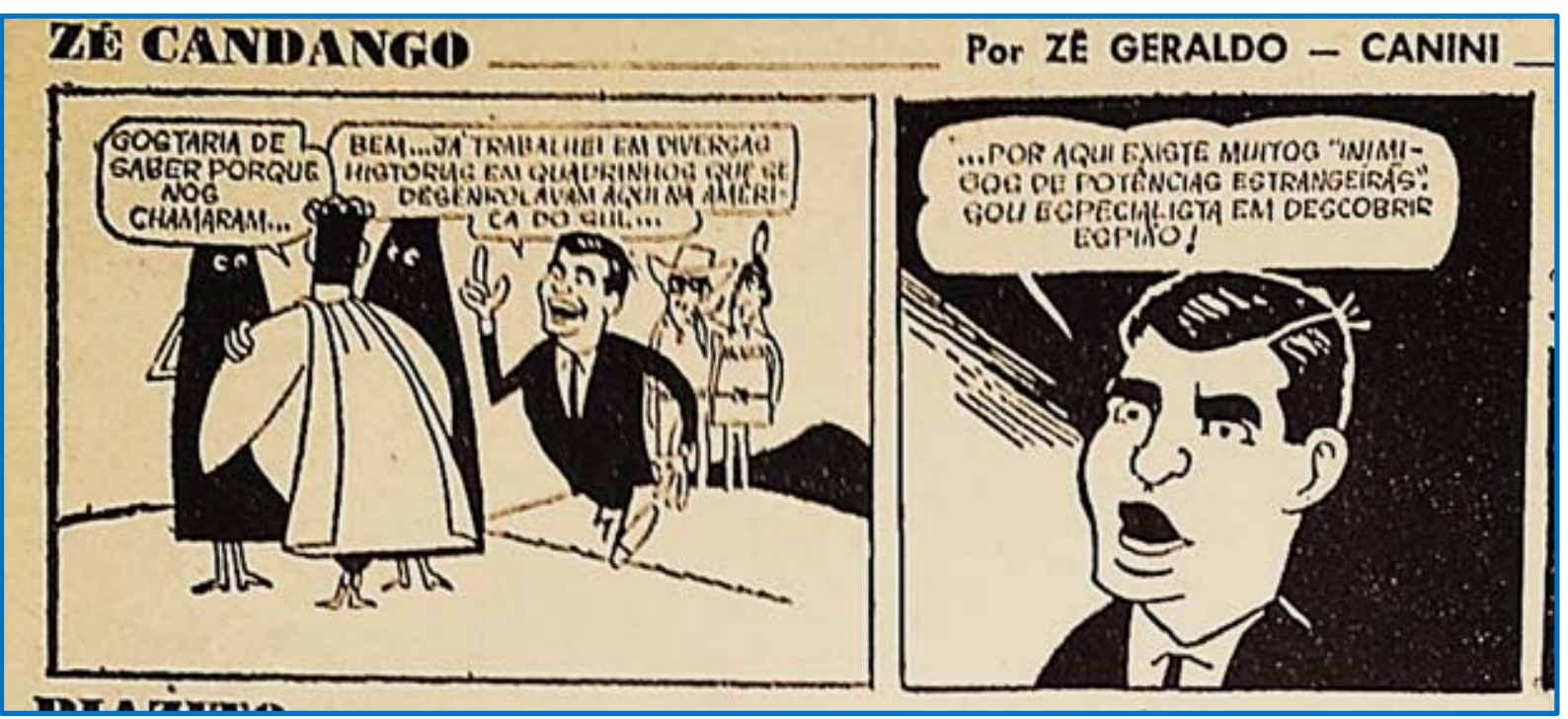

Figura 5 - Jim Gordo em Zé Candango (detalhe).

Fonte: ZÉ CANDANGO. Última Hora, Porto Alegre, 26 out. 1962, p. 20

A lista de personagens das HQs norte-americanas que desfilou nos quadrinhos de Zé Candango prosseguiu ao longo de cada edição da Última Hora gaúcha, possivelmente alimentando a curiosidade dos leitores quanto ao próximo personagem que não escaparia ao traço de Canini e ao texto crítico de José Geraldo. Na tira da CETPA, Superman e Batman foram tratados como super-heróis em pé de igualdade com personagens como Roy Rogers, Mandrake, Popeye e Jim Gordon, o que representava uma interpretação específica dos quadrinhos, distinta do que ocorria nos EUA, por exemplo.

Ao contrário do que poderia ser compreendido como o conceito de "super-herói" nos EUA, eles não eram considerados heróis comuns, e sim tratados indistintamente como "super-homens". Ao que tudo indica, Zé Candango propunha uma associação direta entre personagens de quadrinhos e super-heróis, tratando a todos como sinônimos. Essa atitude se aproximava das orientações presentes na Lei Estadual 2.220/1953, na atuação 
da Comissão Especial do CPOE/RS (VENTORINI, 2009) e das críticas de diversos setores da sociedade brasileira dos anos 1950 e 1960 (JÙNIOR, 2004), que tendiam a associar o gênero super-heróico a toda e qualquer HQ. Com isso, "heróis", "supers" e mesmo figuras ligadas ao cinema de far West eram tratados como sinônimos em Zé Candango. $O$ que unia todos eles era a mesma origem comum, internacional. Dentro dos limites do nacional-popular, a apropriação conceitual dos comics dotava seus personagens de um caráter "super" porque todos eram heróis dos "Estates"4.

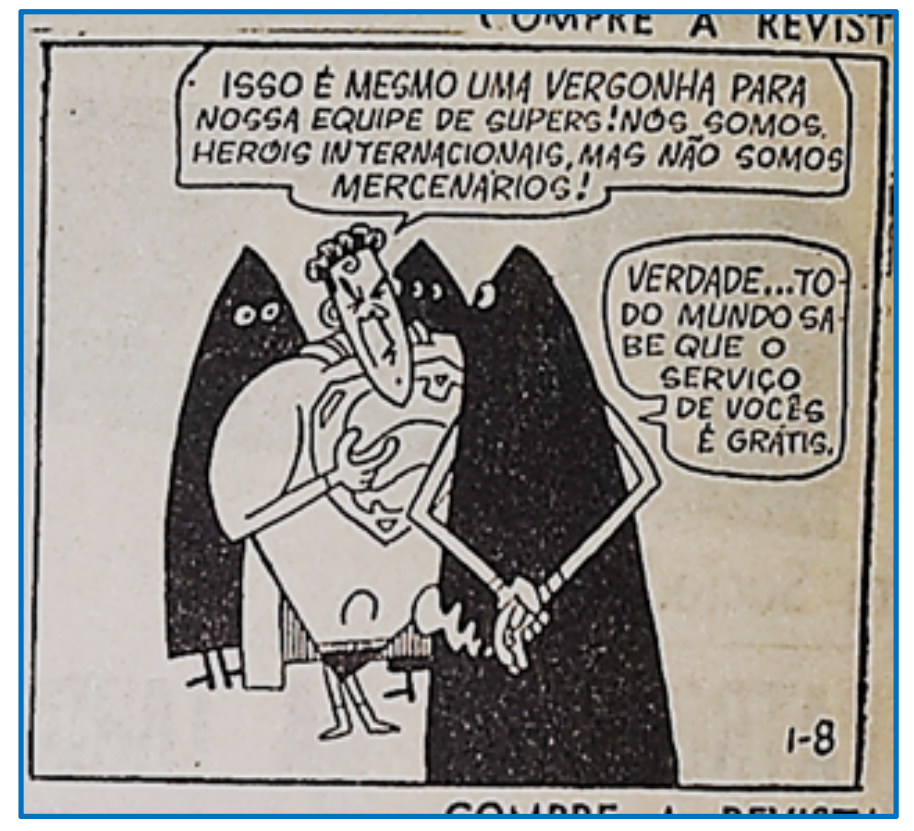

Figura 6 - Sátira aos super-heróis dos "Estates" na Zé Candango (detalhe).

Fonte: ZÉ CANDANGO. Última Hora, Porto Alegre, 24 out. 1962, p. 20

O que explicaria tal apropriação conceitual tão específica em relação à matriz norte-americana? Para além da crítica ao imperialismo cultural dos EUA, hipóteses específicas sobre os quadrinhos podem ser esboçadas para tentar tangenciar a questão. Em primeiro lugar, os super-heróis promoveram uma revolução na indústria do entretenimento jovem. Foram fundamentais para a consolidação do formato das revistas em quadrinhos e suas histórias se espalharam para outras mídias a partir de adaptações para rádio e cinema. Logo se tornaram um componente importante da cultura de massas

\footnotetext{
${ }^{4}$ A historicidade da relação entre conceitos e sociedade é defendida por Reinhardt Koselleck (1992, p. 134146), cujas reflexões serviram de inspiração à compreensão de "super-herói" como uma categoria conceitual em conflito.
} 
norte-americana exportada aos países alinhados ao bloco capitalista nos anos de Guerra Fria. É representativo que a consolidação dos "super” tenha ocorrido no Brasil a partir de 1945, com a fundação da Editora Brasil-América Limitada (EBAL), que reforçava os vínculos com a potência capitalista em seu nome.

De forma complementar, a maneira como as HQs foram introduzidas no Brasil a partir dos syndicates também pode apontar caminhos para responder a questão. Não há dados precisos quanto a isso, mas é possível dizer que, em contraste com o que ocorreu nos Estados Unidos, os quadrinhos de super-herói chegaram quase simultaneamente com títulos de quadrinhos de aventuras e de humor durante os anos de 1930, imprimindo uma nova visualidade e novas práticas de leitura aos leitores habituados com as comics strips veiculadas em revistas ilustradas, como O Tico-Tico, desde 1905. Talvez isso possa ter contribuído para a crítica generalizada aos quadrinhos como uma expressão estrangeira e fora da realidade brasileira. Por sua vez, a especificidade dos super-heróis, protagonistas de um gênero narrativo próprio aos quadrinhos, que viria mesmo a influenciar outros gêneros lançados sob o formato das $\mathrm{HQ}^{5}{ }^{5}$, estimulou a interpretação que reduz todas as manifestações dos quadrinhos a essa abordagem específica.

Por fim, de certo modo, as editoras brasileiras estimularam que tais confusões ocorressem. A principal delas, EBAL, lançou, em 1947, a revista Superman, com Batman, Robin e Super-Homem na capa. Aliás, a tradução do nome do alter-ego de Clark Kent não foi por acaso e serviu para diferenciar a HQ de Siegel e Suster do que a editora compreendia como heróis dos quadrinhos. Ou seja, o título da revista, Superman, também servia de conceito para englobar todos os heróis de HQs lançados por ela, ao passo que Super-Homem designava o personagem específico lançado em 1938. Em seu editorial de estreia, a trajetória editorial dos heróis da "América do Norte" é descrita em tons de aventura:

\footnotetext{
${ }^{5}$ Os exemplos são vários, mas, dentre os mais conhecidos, destaca-se o caso da série The Shadow. Tida como uma das inspirações para Superman, a série originada nos contos pulp logo seria adaptada para as revistas em quadrinhos, não sem antes dotar o seu protagonista de poderes super-heróicos.
} 
No Brasil, os heróis de Superman também são muito conhecidos. Iniciaram-se em uma das nossas revistas juvenis mensais. Passaram para outra. Depois para outra. Voltaram à primeira. Vez em vez ressurgem aqui e além, até que, definitivamente, por contrato feito entre as partes interessadas do Brasil e da América do Norte vão se firmar no Superman - a revista dos cinco continentes ${ }^{6}$.

A confusão entre os gêneros presentes no interior das HQs não deve ser associada, porém, a um desconhecimento das peculiaridades desse formato por parte dos criadores de Zé Candango. As representações gráficas aqui presentes apontam para tratamentos gráficos distintos entre os “heróis” dos quadrinhos. Personagens como Papaye e Brucutu tinham traços praticamente idênticos aos dos originais; detetives e heróis de faroeste eram levemente satirizados. A paródia era concentrada nos personagens Superman, Batman, Fantasma e Lothar - chamado de "Lotação" -, agrupados a partir daquilo que teriam em comum: um uniforme que os diferenciava do restante das pessoas e força física acima da média.

\section{“Não haverá quadrinhos, nem capital”: Quimantú e o super-herói contra a parede}

O caso chileno se aproximou da leitura proposta pela CETPA até certo ponto, na medida em que aprofundou suas críticas do ponto de vista teórico. Diferenciou-se por não ter no humor uma marca de sua linha editorial, o que pode ser justificado a partir do acordo que originou a formação de Quimantú. Como parte das negociações para a compra de parte da editora privada Zig-Zag, foi acordado que a nova editora do Estado receberia um número considerável de revistas em quadrinhos com baixo índice de vendas. Para iniciar de imediato suas atividades, Quimantú optou por manter a publicação desses títulos, num exercício de adaptação de seus conteúdos em contraposição à “indústria cultural” burguesa. Dentre os títulos de Zig-Zag que foram mantidos e reformulados por Quimantú, nenhum dialogava diretamente com humor; mesmo quando Quimantú começou a lançar títulos próprios, foi bastante tímida na opção por quadrinhos direcionados ao humor. Afora o caso particular da revista La Firme e de HQs esporádicas

\footnotetext{
${ }^{6}$ EBAL. Superman, n. 1, nov. 1947.
} 
presentes em alguns títulos, a única revista voltada para o humor foi Ganso, cujo primeiro número veio a público em setembro de 1973, mês do golpe que derrubou Allende e encerrou as atividades de Quimantú. Em todo caso, no primeiro número de Ganso não constavam paródias de super-heróis?

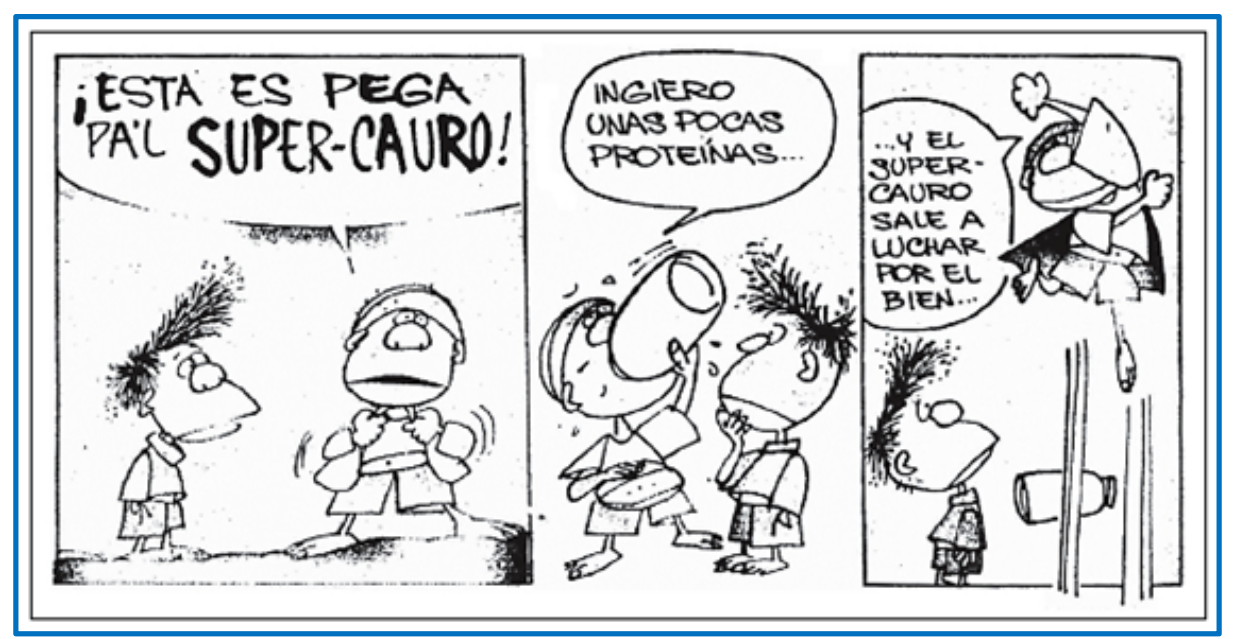

Figura 7 - Supercauro (detalhe), de Pepe Huinca (apud. FLORES, 2012, p. 614).

Por não estar diretamente vinculada à área de HQs de Quimantú, a revista La Firme não é contemplada pelo recorte aqui sugerido, embora seja objeto de discussão de outros estudiosos das HQs de Quimantú (KUNZLE, 1978; FLORES, 2012). Vale mencionar, porém, o personagem Supercauro, publicado ao longo de algumas edições da revista em quadrinhos de educação política.

O protagonista era um menino pobre e de aspecto físico mirrado que adquiria poderes especiais após alimentar-se bem. Na imagem abaixo, o personagem se tornou Supercauro após ingerir "proteínas", possivelmente através do leite, preocupação do governo da UP sintetizada na campanha de distribuição de meio litro diário de leite às crianças chilenas. A campanha de distribuição de leite pela UP se tornaria, de acordo com Zárate (2010, p. 184), um dos "imaginários emblemáticos associados à experiência socialista", ao ponto de ser alvo da desconstrução crítica da ditadura que lhe seguiu.

\footnotetext{
${ }^{7}$ QUIMANTÚ. Ganso, n. 1, Santiago de Chile, set. 1973.
} 
Apesar dos poderes, Supercauro não resolvia os problemas com base na força física, derrotando inimigos como o mercado negro, o analfabetismo, a fuga de dólares, greve do cobre e os inimigos das empresas estatais a partir do raciocínio e da organização coletiva, demonstrando que os super-heróis não eram necessários (FLORES, 2010, p. 586587).

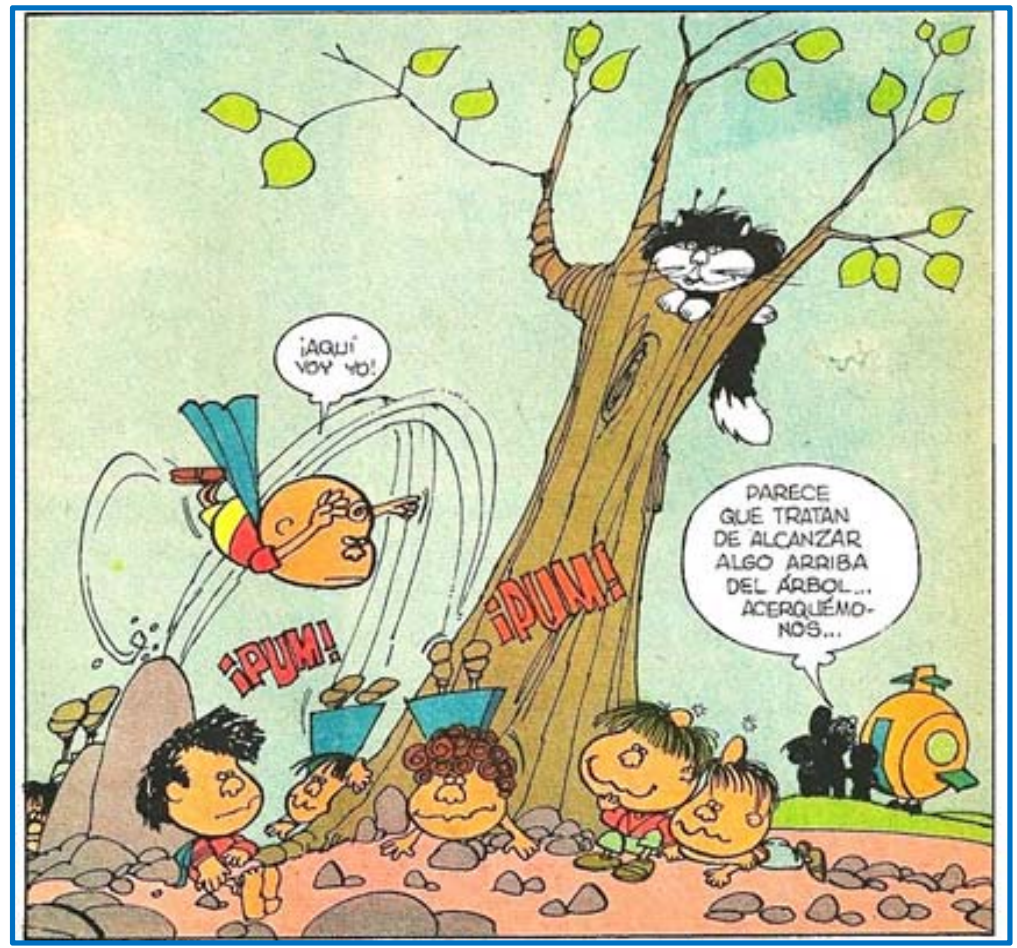

Figura 8 - Año 2.200 (detalhe), de Guidú e Saúl Schkolnik.

Fonte: QUIMANTÚ. Cabrochico, n. 3, Santiago de Chile, 1971, p. 10

O traço simples, a abordagem paródica e crítica em relação ao cânone superheróico e o contraste entre fantasia e realidade seriam recursos trabalhados em outra HQ de Quimantú. Año 2.200, desenhada por Guidú a partir de roteiros de Saúl Schkolnik, foi um quadrinho de ficção científica que se alimentava do imaginário da Guerra Fria em torno da corrida espacial para tecer comentários sobre a realidade chilena. A HQ, publicada no terceiro número de Cabrochico, teve como tema o papel do super-herói na vida das crianças de um planeta distante ${ }^{8}$. Após um chamado de alerta, os personagens Gagarito, Próton e companhia aterrissaram sua nave e se viram às voltas com uma cena inusitada.

\footnotetext{
${ }^{8}$ QUIMANTÚ. Cabrochico, n. 3, Santiago de Chile, 1971, p. 09-16.
} 


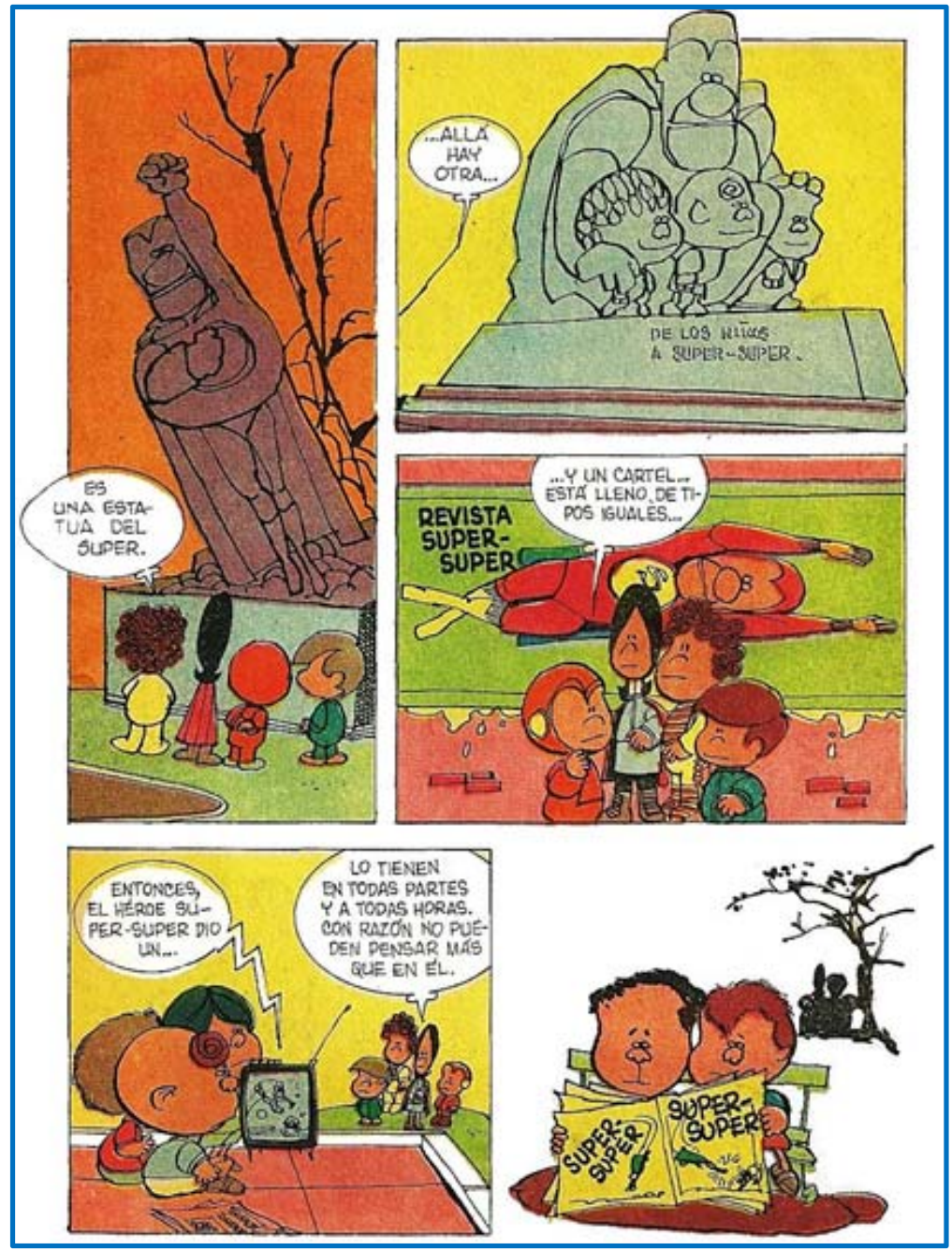

Figura 9 - Año 2.200, de Guidú e Saúl Schkolnik.

Fonte: QUIMANTÚ. Cabrochico, n. 3, Santiago de Chile, 1971, p. 13

A situação foi logo esclarecida: inspiradas no personagem Super-Super e dotadas de capas que remetem ao personagem paradigmático da DC Comics, as crianças se atiraram de uma pedra em direção a uma árvore na esperança de voar e, assim, salvar o mascote Miú, que não conseguia descer do topo de uma árvore. As seguidas tentativas fracassaram e todos manifestavam incômodo em seus rostos, quando não carregavam hematomas na cabeça. Mesmo após a realidade provar a falácia dos contos superheróicos, os meninos seguiram fiéis ao ícone dos comics, ao ponto de atacarem a pedradas Gagarito e seus amigos - tudo porque eles afirmaram que Super-Super não passava de um "conto". Logo ficou claro para os protagonistas o poder de Super-Super 

anúncios publicitários e monumentos públicos, os super-heróis seriam um "lugar de memória" incômodo para o projeto socialista de emancipação humana. Contra a individualização extraordinária das ações, o trabalho em equipe defendido por Cabrochico trazia o desenrolar da narrativa. O quadro se alterou apenas quando um dos garotos, ao realizar mais um salto, machucou a cabeça e precisou dos socorros médicos dos personagens chilenos que, prontamente, propuseram a cooperação coletiva como uma estratégia para alcançarem, juntos, a mascote. Os meninos constatam, por fim, que não precisavam mais de Super-Super para solucionar seus problemas, e agradeceram aos protagonistas, que partiram de volta ao espaço.

A redução cômica do mundo das HQs de super-heróis e seus leitores foi uma exceção dentro do projeto editorial de Quimantú e deve ter agradado os editores de Cabrochico, que retomaram um dos quadros da $\mathrm{HQ}$ em suplemento voltado aos pais. $\mathrm{O}$ objetivo era explicar a eles a proposta política da revista que, em suas quatro primeiras edições, não medira esforços na desconstrução crítica de diversas narrativas e personagens que habitavam o imaginário social das crianças chilenas até então. Em resposta a cartas que a revista teria recebido e à repercussão observada a partir dos primeiros exemplares ${ }^{9}$, os editores de Cabrochico se viram compelidos a anexar à revista um suplemento de esclarecimento aos pais, no qual argumentavam a favor da proposta da revista.

Após a crítica aos contos de fada, a atenção se direcionou aos quadrinhos, dentre os quais os de super-heróis. Ao falar deles, o suplemento da revista questionou se os pais realmente deveriam acreditar que um homem sozinho tem condições de solucionar todos os problemas do "nosso país e do mundo" e se, na verdade, os progressos e os problemas de cada um não deveriam ser solucionados a partir da união e da cooperação em equipe. Em vez de apoiar o individualismo valorizado entre os super-heróis, os pais

${ }^{9}$ QUIMANTÚ. Cabrochico, n. 5, Santiago de Chile, 1971, p. 22-23. 
deveriam apoiar narrativas que incentivassem a "união de todos os chilenos para o progresso do país", convocando-os para, juntos, "mostrar que é melhor ajudar uns aos outros, como nós adultos", em vez de ficar esperando pelo Superman ${ }^{10}$.

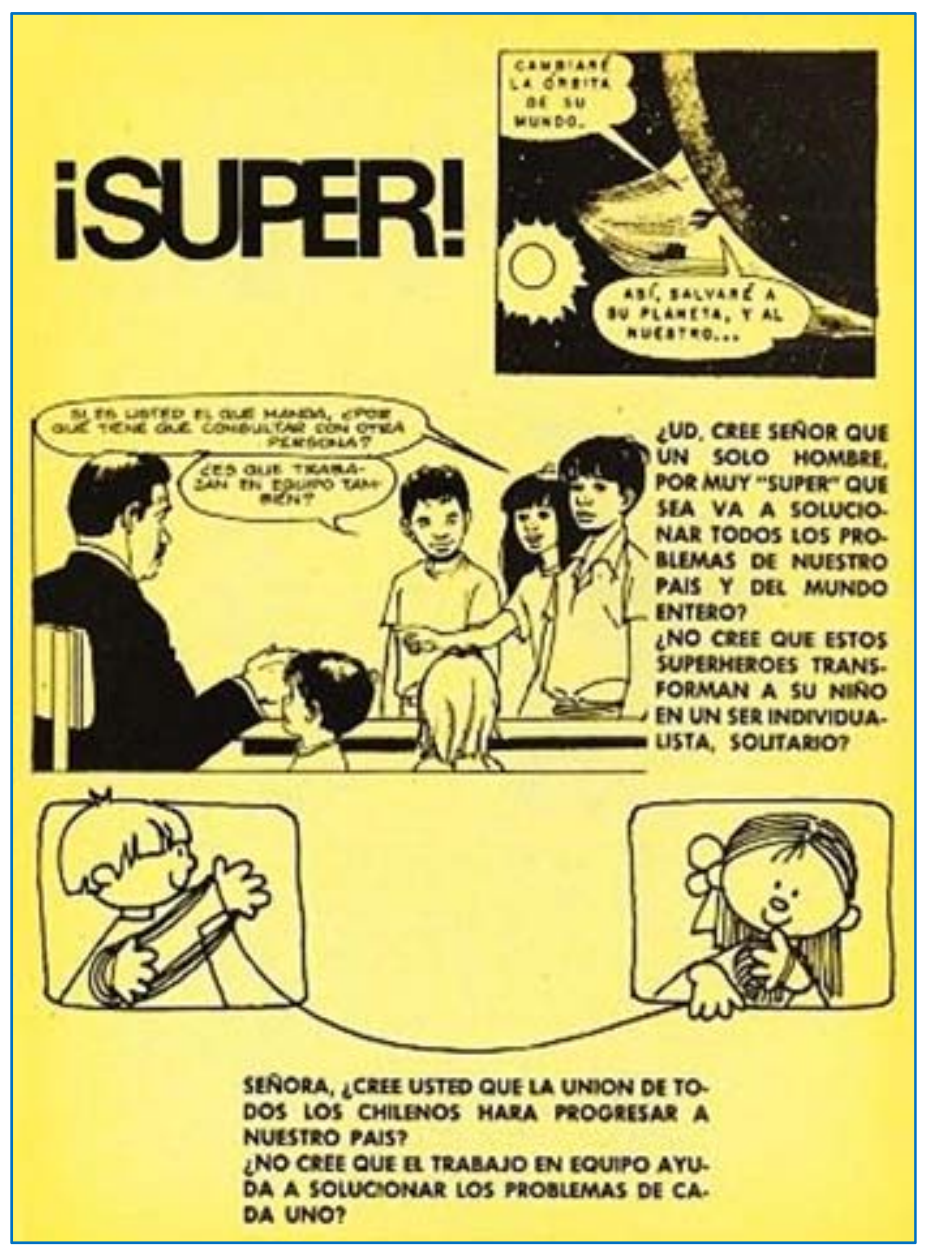

Figura 10 - Suplemento para os pais em Cabrochico.

Fonte: QUIMANTÚ. Cabrochico, n. 5, Santiago de Chile, 1971, p. 30.

Na página seguinte, o suplemento problematizou o etnocentrismo presente em HQ da Disney que tratava os "estúpidos nativos" de forma depreciativa; e até mesmo os quadrinhos de terror não escaparam das críticas por seu conteúdo considerado moralmente degradante e violento. No lugar dessas publicações, deveriam ser estimuladas as HQs que primassem pela cooperação e união dos chilenos, e que

\footnotetext{
${ }^{10}$ Ibidem, p. 33.
} 
discussões sobre os sentidos dos quadrinhos que povoavam a imprensa e os debates acadêmicos desde meados dos anos de 1960 no Chile. Ao lado de Para leer al Pato Donald, o livro Superman y sus amigos del alma forneceu dados preciosos para o debate acerca dos sentidos sociais dos quadrinhos no Chile socialista. Resultado de pesquisas realizadas no interior de Quimantú entre 1971 e 1972, foi escrito mais uma vez por Ariel Dorfman, dessa vez em parceria com o sociólogo Manuel Jofré e publicado apenas em 1974, na Argentina. Quando do golpe que levou à derrocada da UP, o livro se encontrava em fase final de produção, pronto para encadernação e com título inicial de "Documentos secretos sobre a vida íntima do Super-Homem e seus companheiros d’alma”, provável referência a livro de bastante sucesso na época, lançado por Quimantú em abril de 1972 (DORFMAN, 1978, p. 16) $)^{12}$.

No prólogo original, que teria sido escrito no formato de quadrinhos e perdido durante a apreensão do livro pelos militares, Dorfman afirmou que buscavam "relacionar a ideologia que se agitava por trás dos companheiros d'alma do super-herói com as tentativas insurrecionais das classes dominantes, destituídas de poder executivo no Chile ${ }^{13 \prime \prime}$ (DORFMAN, JOFRÉ, 1978, p. 15-16). Tal como Gagarito e seus amigos, os autores pressentiam que o Super-Homem "estava em todos os cantos do Chile" e se tornara "o mais perigoso" adversário a ser combatido (DORFMAN, JOFRÉ, 1978, p. 15-16). Para tanto, escreveram o livro.

A segunda parte da obra, escrita por Manuel Jofré, dedicou-se à análise das revistas em quadrinhos publicadas no Chile durante o primeiro ano de atuação de Quimantú. Escrito numa linguagem que transita entre o ensaio e o panfleto político, o

\footnotetext{
${ }^{11}$ Ibidem, p. 30-31, 34, 30, 32, 33, 35.

${ }^{12}$ Documentos secretos de la ITT. Santiago de Chile: Quimantú, 1972.

${ }^{13}$ Ao longo da obra, a noção de "ideologia" é trabalhada a partir do referencial marxiano que a define como "falsa consciência", conforme a famosa citação de Marx e Engels: "E, se, em toda a ideologia, os homens e suas relações nos aparecem de cabeça para baixo como numa câmera escura, esse fenômeno decorre de seu processo de vida histórico, exatamente como a inversão dos objetos na retina decorre de seu processo de vida diretamente físico" (MARX, ENGELS, 2001, p. 19).
} 
livro partiu de referências teóricas gerais como Umberto Eco e Roland Barthes - além de Dorfman e Mattelart, é claro - para definir as características dos quadrinhos no mundo capitalista de então. De início, apontou que a revista em quadrinhos era socialmente forjada como um entretenimento pretensamente inocente e que, por isso, idealizava uma criança como leitora, infantilizando sua apreensão. O caráter evasivo dos quadrinhos, porém, deveria ser entendido à luz das relações sociais de produção e, interior do capitalismo, configurava-se como uma forma de compensação ideológica diante da alienação do mundo capitalista. Interpondo-se entre os trabalhadores e a sua realização inevitável de emancipação revolucionária, Jofré sentenciou: “o homem deve observar-se para saber-se pobre econômica e humanamente: os quadrinhos o impedem" (JOFRÉ, 1978, p. 91).

Concebida como a principal editora do Estado chileno, cabia à Quimantú a responsabilidade de fomentar a prática de leitura a partir de livros, revistas de variedades e revistas em quadrinhos, o que exigia que estas últimas fossem submetidas à análise crítica. Inserido no interior do que se avaliava como uma experiência democrática de transição socialista, o exercício proposto por Jofré, consistia em disputar os meios de comunicação a partir da crítica ideológica e, com isso, auxiliar na construção da nova sociedade, dotada de valores novos:

Os quadrinhos são uma arma. Os meios de comunicação são uma arma. Mas o uso que fazemos dela não é pra matar, mas para defender. Porque nossas armas são outras. A verdade, a liberdade, a realização humana, o tudo em todos, a unidade dos seres humanos. No socialismo não existirão armas. No socialismo não haverá homicídios. No socialismo não existirão homens que matem outros homens, nem com trabalho nem com nenhuma arma. Porque não haverá balas nem armas, não haverá quadrinhos nem capital. Não haverá falsas riquezas. (DORFMAN, JOFRÉ, 1978, p. 93)

Jofré prosseguiu elencando uma série de valores ideológicos subjacentes às revistas em quadrinhos, defendendo como a rapidez da ação e sua "estrutura eminentemente pragmática" contribuía para o fortalecimento de uma mensagem única, na qual os "valores da ideologia burguesa" carregados pelos personagens eram 
absorvidos pelos leitores. Para ele, os leitores eram escamoteados a partir das ideias de entretenimento e inocência historicamente difundidas pelos meios de comunicação. Jofré estabeleceu que a história em quadrinhos:

Nega ou deforma o fato histórico de que existem países desenvolvidos e subdesenvolvidos (fixando o espaço das histórias em quadrinhos numa terra de ninguém, como, por exemplo, nos casos do Oeste, da selva ou da Cidade Gótica de Batman), [...] nega a transformação social (propondo um mundo circular onde sempre triunfam os super-heróis, seja Batman, Tarzan ou o Zorro), [...] nega as contradições insuperáveis do capitalismo (com o super-herói superando os problemas de justiça), [...] nega o social (ao mostrar os bons sempre sozinhos), nega a humanidade (colocando o super-herói como um Messias que impõe a justiça e a ordem, convertendo-o em um ser supratemporal dotado de poderes eternos), nega a justiça de classes (fazendo com que o superherói solucione os problemas que a justiça não pode resolver), [...] nega a liberdade (o super-herói castiga os que se rebelam, prendendo-os, ou recapturando-os para o sistema), [...] nega o trabalho (os personagens estão sempre ociosos), nega a criação (originando um mundo repetitivo) e claro que, além de negar muitíssimas coisas mais, a ideologia das histórias em quadrinhos nega a si própria (nunca nenhum personagem as lê). (JOFRÉ, 1978, p. 95-96).

Afora a prosa carregada de denúncias e de um tom acusatório, com negações que ocuparam quase uma página inteira, merece destaque o fato de Jofré não distinguir os gêneros narrativos existentes no interior das HQs. De fato, tal como observado nas tiras de Zé Candango, quadrinhos ambientados na selva ou no Velho Oeste foram colocados no mesmo patamar de narrativas super-heróicas de personagens como Batman, por exemplo.

A orientação de alocar personagens de HQs de gêneros tão distintos em abordagens comuns é seguida ainda hoje por outras análises europeias dos quadrinhos. Mesmo tendo sido superadas as inflexões estruturalistas presentes nas orientações teóricas de Jofré, pouco são enfatizadas as diferenças entre heróis e super-heróis. Savramis (1986, p. 254-264) constata o diálogo entre Superman e Tarzan, unindo a HQ de super-herói com influência de ficção científica à versão quadrinizada da obra de Burroughs a partir da religião e do desejo de transcendência das conjecturas da vida moderna, ou os artigos de Prévost (2014, p. 47-64) e Levet (2014, p. 69-81), que 
Ainda que Jofré tenha esboçado uma diferenciação entre os gêneros de quadrinhos ao afirmar que os super-heróis são "uma das tendências mais difundidas da revista de história em quadrinhos", a análise partiu deles para generalizar a interpretação sobre os quadrinhos como um todo. Neste sentido, Superman e seus "amigos do peito" como os “super-heróis" do faroeste Zorro e Roy Rogers, Fantasma e Tarzan, Dick Tracy, Flash Gordon, Príncipe Valente e, é claro, Super Mouse - seriam usurpadores do papel transformador da realidade, intrínseco ao perfil de classe do proletariado. De acordo com Jofré, em seu lugar, os super-heróis propunham a supressão de qualquer conflito. Em mais uma de suas frases célebres, Jofré (1978, p. 101-102, p. 96) estabeleceu que "em um mundo protegido pelo Super-Homem, Marx e Che Guevara são desnecessários”.

A análise de Jofré sobre os quadrinhos seguiu nessa toada, elencando uma série de características presentes em qualquer história em quadrinhos. Fragmentação e naturalização da realidade, maniqueísmo, individualismo, relações verticais de poder, ênfase na aventura em relação ao tempo cotidiano e no quantitativo sobre o qualitativo, legalismo, irracionalismo e preconceitos de classe e de raça foram alguns dos elementos elencados como constituintes da "história em quadrinhos tradicional burguesa", de Superman a Dick Tracy (JOFRÉ, 1978, p. 101-103). Cabrochico, principal projeto editorial de Quimantú voltado para a publicação de quadrinhos distintos daqueles que até então teriam disseminado "valores ideológicos da burguesia", pode ser compreendida como a tentativa de colocar em prática tais leituras, o que pode ser percebido na sua crítica generalizada a todas as narrativas juvenis - dos contos de fada aos diversos gêneros presentes nos quadrinhos.

Até mesmo algumas propagandas de produtos veiculadas em Cabrochico se nutriam das discussões em torno das imagens de heroísmo a serem transmitidas para as crianças chilenas. A Figura 5.11 associa a força obtida após o consumo de leite aos esforços do pai, “um trabalhador de primeira”. 


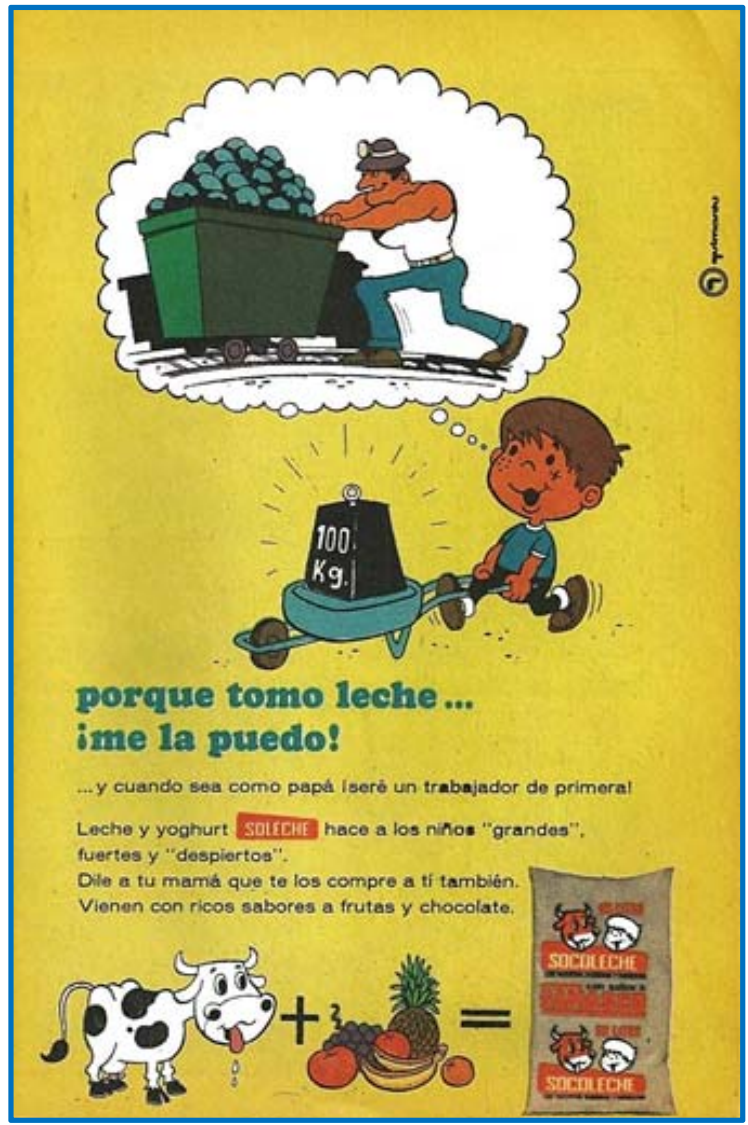

Figura 11 - Anúncio publicitário em Cabrochico.

Fonte: QUIMANTÚ. Cabrochico, n. 4, Santiago de Chile, 1971, p. 43

O corpo super-heróico, que mereceu atenção em Zé Candango e Año 2.200, novamente ocupou espaço central, dessa vez na publicidade. A saúde e a educação física, elementos importantes da cultura visual de regimes socialistas como o soviético (O’MAHONY, 2006), também foram temas importantes para a visualidade do projeto socialista chileno, ocupando espaços em suplementos específicos de Cabrochico, por meio de receitas econômicas e originais, recomendações de saúde e orientações sobre vitaminas e medicamentos, entre outros ${ }^{14}$. Em Quimantú, a revista esportiva Estadio alterou sua linha editorial, substituindo a cobertura exclusiva de times de futebol, turfe e esportes internacionais a favor de reportagens sobre práticas desportivas comunitárias e dicas de saúde.

\footnotetext{
${ }^{14}$ Por exemplo, cf. QUIMANTÚ. Cabrochico, n. 3, Santiago de Chile, p. 22-36. QUIMANTÚ. Cabrochico, n. 4, Santiago de Chile, p. 22-36.
} 
No caso dos quadrinhos, a defesa de um corpo contra-hegemônico à dominação cultural e política norte-americana passava pela desconstrução do corpo super-heróico. Tidos como invulneráveis e livres de marcas, localizados acima de qualquer determinação histórica, destacados acima dos cidadãos comuns e tratados como celebridades (BUKATMAN, 2013, p. 179), os Super-Supers deveriam ser sobrepujados por outros heróis nacionais. Para tanto, o passado local era um prato cheio para a introdução de novos (super-)heróis no cânone dos quadrinhos brasileiros e chilenos.

\section{Conclusão}

A despeito das diferenças, um ponto em comum aproxima CETPA e Quimantú: o tratamento dedicado à figura do super-herói das HQs. Com isso, o papel paradigmático da narrativa de super-herói no interior das histórias em quadrinhos serve de pano de fundo para que as iniciativas editoriais de HQs brasileiras e chilenas produzam interpretações sobre ela e, de forma mais ampla, sobre as histórias em quadrinhos em geral. Procurou-se apontar algumas das orientações e critérios que nortearam as criações de HQs de CETPA e Quimantú, com vistas a discutir o impacto que tal mídia alcançou no cenário latinoamericano de Guerra Fria.

As diferenças entre elas não devem ser ofuscadas a despeito das aproximações propostas, o que obrigou a formulação de uma narrativa histórica que contemple tanto os “jogos de escalas" (REVEL, 1998, p. 15-38) quanto uma "história cruzada"15" (WERNER, ZIMMERMAN, 2003, p. 07-36), a favor da construção social dos sentidos dos quadrinhos no Brasil e no Chile. É possível concluir que a América Latina possui uma história editorial e visual própria das HQs a ser ainda contada, em que os embates envolvendo a produção local e o material estrangeiro são elementos paradigmáticos para a sua construção como atividade cultural.

A coincidência de CETPA e Quimantú intitularem seus super-heróis parodiados como "Super-Super" deve ir além da mera curiosidade anedótica. Ela é indicativa de que

\footnotetext{
${ }^{15}$ As aspas se referem, respectivamente, a REVEL, Jacques. Microanálise e construção do social. In: REVEL, J. (Org.), op. cit. E a WERNER, Michael; ZIMMERMAN, Bénedict, op. cit.
} 
as circulações de sentido sobre uma prática cultural ultrapassam as divisas nacionais. É possível compreendê-las, seguindo Appadurai (2008, p. 15-88), como dotadas de uma "vida social”, cuja "biografia cultural” implica nas circulações de sentidos e práticas que ultrapassam fronteiras historicamente artificiais, como o Estado-Nação, por exemplo. A partir das realidades regional e nacional das editoras CETPA e Quimantú, o que se observa é que as HQs se constituem como prática cultural a partir das circulações e apropriações de sentidos presentes a partir das diferentes interações entre essas escalas de análise, o que aponta para uma história transnacional dos quadrinhos.

\section{Referências}

APPADURAI, Arjun. Introdução: mercadorias e a política de valor. In: APPADURAI, Arjun (Org.). A vida social das coisas: as mercadorias como bem cultural. Niterói: EDUFF, 2008, p. 15-88.

ARGUMEDO, Alcira. Los silencios y las voces en América Latina: notas sobre el pensamiento nacional y popular. Buenos Aires: Colihue, 2009.

BUKATMAN, Scott. A song for the urban superhero. In: HATFIELD, Charles; HEER, Jeet; WORCESTER, Kent (Org.). The superhero reader. Jackson: University Press of Mississippi, 2013. p. 170-198.

DOCUMENTOS secretos de la ITT. Santiago de Chile: Quimantú, 1972.

DORFMAN, Ariel. Prólogo no qual se mostram super-homens de verdade em ação. In: DORFMAN, Ariel; JOFRÉ, Manuel. Super-homem e seus amigos do peito. Rio de Janeiro: Paz e Terra, 1978. p. 15-18.

EBAL. Superman, n. 1, nov., 1947.

FLORES, Jorge Rojas. Historia de la infancia en el Chile republicano, 1810-2010. Santiago de Chile: JNJI, 2010.

FLORES, Jorge Rojas. Representaciones de la infancia en el espacio de las historietas, 1900-1980. Revista Chilena de Pediatria, v. 6, n. 83, p.614, 2012. 
GABILLIET, Jean-Paul. "Fun in four colors": comme la quadrichromie a créé la bande dessinée aux États-Units. Transatlantica, v. 4, n. 1, p. 1-8, 2005.

GABILLIET, Jean-Paul. Of comics and men: a cultural history of American comic books. Jackson: University Press of Mississippi, 2010.

GENÉ, Marcela. "Sisebutas" en Buenos Aires. Family strips de los años veinte. Antíteses, v. 5, n. 9, p. 181-204, jan./jul. 2012.

GROESTEEN, Thierry. Parodies: la bande dessinée au second degré. Paris: Skira Flammarion, 2010.

HATFIELD, Charles; HEER, Jeet; WORCESTER, Kent (Orgs.). The superhero reader. Jackson: University Press of Mississippi, 2013.

HEER, Jeet; WORCESTER, Kent (Orgs.). A comics studies reader. Jackson: University Press of Mississipi, 2009.

HUTCHEON, Linda. Uma teoria da paródia: ensinamento das formas de arte do século XX. Lisboa: Edições 70, 1989.

JAMESON, Fredric. Pós-modernidade e sociedade de consumo. Novos estudos CEBRAP, São Paulo, n. 12, p.16-26, jun., 1985.

JENNINGS, John. Superheroes by design. In: ROSENBERG, Robin; COOGAN, Peter (Orgs.). What is a superhero? New York: Oxford University Press, 2013, p. 59-63.

JOFRÉ, Manuel. As histórias em quadrinhos e suas transformações. In: DORFMAN, Ariel; JOFRÉ, Manuel. Super-homem e seus amigos do peito. Rio de Janeiro: Paz e Terra, 1978. p. 87-171.

JÚNIOR, Gonçalo. A Guerra dos gibis: formação do mercado editorial brasileiro e a censura nos quadrinhos. 1933-64. São Paulo: Companhia das Letras, 2004.

KOSELLECK, Reinhardt. Uma história dos conceitos: problemas teóricos e práticos. Estudos históricos, Rio de Janeiro, v. 5, n. 10, p. 134-146, 1992.

KUNZLE, David. Chile's La Firme versus Itt. Latin American Perspectives, v. 5, n. 1, p. 119133, jan., 1978. 
LEVET, Natacha. Sherlock Holmes, du surhomme au supérheros. In: BOUCHER, FrançoisEmmanüel; DAVID, Sylvain; PRÉVOST, Maxime (Orgs.). Mythologies du superhéros.

Histoire, phylosophie, géographie, intermédialités. Liège: Universitaires de Liège, 2014. p. 69-81.

MACDOUGALL, Curtis. Newspaper syndication and its social significance. Annals of the American Academy of Political and Social Science, v. 219, s/n, p. 76-81, jan. 1942.

MARX, Karl; ENGELS, Friedrich. A ideologia alemã. São Paulo: Martins Fontes, 2001.

O'MAHONY, Mike. Sport in the USSR: physical culture-visual culture. London: Reaktion Books, 2006.

PEREIRA, Priscila. Entre a épica e a paródia: a (des) mistificação do gaúcho nos quadrinhos de Inodoro Pereyra, el renegau. 2011. Dissertação (Mestrado em História) Universidade Estadual de Campinas, Instituto de Filosofia e Ciências Humanas, Campinas, 2011.

PRADO, Maria Lígia. Repensando a história comparada da América Latina. Revista de História, São Paulo, n. 153, p. 11-33, jul./dez. 2005.

PRÉVOST, Maxime. Mais où sont les superhéros d'antan? Porthos, Obélix et la puissance rétrospective. In: BOUCHER, François-Emmanüel; DAVID, Sylvain; PRÉVOST, Maxime (Orgs.). Mythologies du superhéros.. Histoire, phylosophie, géographie, intermédialités. Liège: Universitaires de Liège, 2014, p. 47-67.

QUIMANTÚ. Ganso, n. 1, Santiago de Chile, set. 1973.

QUIMANTÚ. Cabrochico, n. 3, Santiago de Chile, 1971.

QUIMANTÚ. Cabrochico, n. 4, Santiago de Chile, 1971.

QUIMANTÚ. Cabrochico, n. 5, Santiago de Chile, 1971.

REVEL, Jacques. Microanálise e construção do social. In: REVEL, Jacques (Org.). Jogos de escalas: a experiência da microanálise. Rio de Janeiro: Ed. FGV, 1998. p. 15-38.

SAVAGE JR., William. Comic books and America, 1945-1954. Norman: University of Oklahoma Press, 1990. 
SAVRAMIS, Demosthenes. Der moderne Mensch zwischen Tarzan und Superman. In: SILBERMANN, Alphons; DYROFF, H.-D. (Org.). Comics and visual culture: research studies from 10 countries. München, New York, London, Paris: Saur, 1986, p. 254-264.

SLATTA, Richard W. The cowboy encyclopedia. Santa Barbara: ABC-Clio, 1994.

SMOLDEREN, Thierry. Naissances de la bande dessinée. De William Hogarth à Winsor McCay. Bruxelas: Les Impressions Nouvelles, 2009.

STEIN, Daniel; DENSON, Shane; MEYER, Christina (Org.). Transnational perspectives on graphic narratives. Comics at the crossroads. London/New York: Bloomsbury, 2013.

VENTORINI, Eliana. Regulação da leitura e da literatura infanto-juvenil, no Rio Grande do Sul, na década de 50: interdição, triagem e intervenção das autoridades. 2009. Dissertação (Mestrado em Educação) - Universidade Federal do Rio Grande do Sul, Faculdade de Educação, Porto Alegre, 2009.

ÚLTIMA HORA, Porto Alegre, 20 out. 1962.

ÚLTIMA HORA, Porto Alegre, 22 out. 1962.

ÚLTIMA HORA, Porto Alegre, 23 out. 1962.

ÚLTIMA HORA, Porto Alegre, 24 out. 1962.

ÚLTIMA HORA, Porto Alegre, 26 out. 1962.

ÚLTIMA HORA, Porto Alegre, 20 nov. 1962.

ÚLTIMA HORA, Porto Alegre, 29 nov. 1962.

ÚLTIMA HORA, Porto Alegre, 07 dez. 1962.

ÚLTIMA HORA, Porto Alegre, 08 dez. 1962.

WERNER, Michael ; ZIMMERMANN, Bénedict. Penserl'histoire croisée: entre empirie et reflexivité. Annales, v. 58, n. 1, p. 07-36, jan./fev. 2003.

WRIGHT, Bradford. Comic book nation: the transformation of youth culture in America. Baltimore: The John Hopkins University Press, 2001. 
ZÁRATE, Verónica Valdivia Ortiz de. “¡Estamos en guerra, señores!”. El régimen militar de Pinochet y el "pueblo", 1973-1980. Historia, v. 1, n. 43, p. 163-201, jan./jul. 2010. 